\title{
Caribbean Crazy Ant (proposed common name), Paratrechina pubens Forel (Insecta: Hymenoptera: Formicidae: Formicinae) $)^{1}$
}

John Warner and Rudolph H. Scheffrahn ${ }^{2}$

\section{Introduction}

Over the last few years reports have escalated of a golden-brown to reddish-brown "crazy ant" infesting properties in and around West Palm Beach, Florida. Thick foraging trails with thousands of ants occur along sidewalks, around buildings, and on trees and shrubs. Pest control operators using liquid and/or granular broad-range insecticides appear unable to control this nuisance ant.

\section{Distribution}

Paratrechina pubens Forel (1893) was described from St. Vincent, Lesser Antilles, and has been found on other West Indian islands, including Anguilla, Guadeloupe, and Puerto Rico (Trager 1984). Samples of $P$. pubens collected in Coral Gables and Miami, Florida, date from 1953 (Trager 1984). Klotz et al. (1995) report infestations in Boca Raton, Homestead, and Miami and state that "in 1990, hundreds of these ants were found on the second floor of a large Miami hospital." Deyrup et al. (2000) report that it "is abundant on the campus of the University of Miami, where it resembles a pale $P$. bourbonica, foraging on sidewalks and running up and down tree trunks." $\mathrm{L}$. Davis, Jr. (2003 personal communication) has seen these ants from Everglades National Park, Fort Lauderdale, Jacksonville, and Port St. Lucie. Specimens from Sarasota (F. Santana 2003, personal communication) were also confirmed. These ants seem to have large populations where they occur and are considered a pest in Colombia (Davis 2003, personal communication).

In the West Palm Beach area, two heavily infested sites were observed about 3 miles west of the Intracoastal Waterway. These sites are adjacent to a utility right-of-way running to the port of Palm Beach (site of a Florida Power and Light electrical generating plant). The port may have been the point of debarkation of P. pubens into Palm Beach County.

1. This document is EENY-284 one of a series of Featured Creatures from the Entomology and Nematology Department, Florida Cooperative Extension Service, Institute of Food and Agricultural Sciences, University of Florida. Published: March 2003. Revised: February 2004. This document is also available on Featured Creatures Website at http://creatures.ifas.ufl.edu. Please visit the EDIS Website at http://edis.ifas.ufl.edu. Additional information on these organisms, including many color photographs, is available at the Entomology and Nematology Department website at http://entnemdept.ifas.ufl.edu/.

2. John Warner and Rudolph H. Scheffrahn, Department of Entomology and Nematology, Ft. Lauderdale Research and Education Center, University of Florida, Ft. Lauderdale.

The Institute of Food and Agricultural Sciences (IFAS) is an Equal Opportunity Institution authorized to provide research, educational information and other services only to individuals and institutions that function with non-discrimination with respect to race, creed, color, religion, age, disability, sex, sexual orientation, marital status, national origin, political opinions or affiliations. U.S. Department of Agriculture, Cooperative Extension Service, University of Florida, IFAS, Florida A. \& M. University Cooperative Extension Program, and Boards of County Commissioners Cooperating. Larry Arrington, Dean 


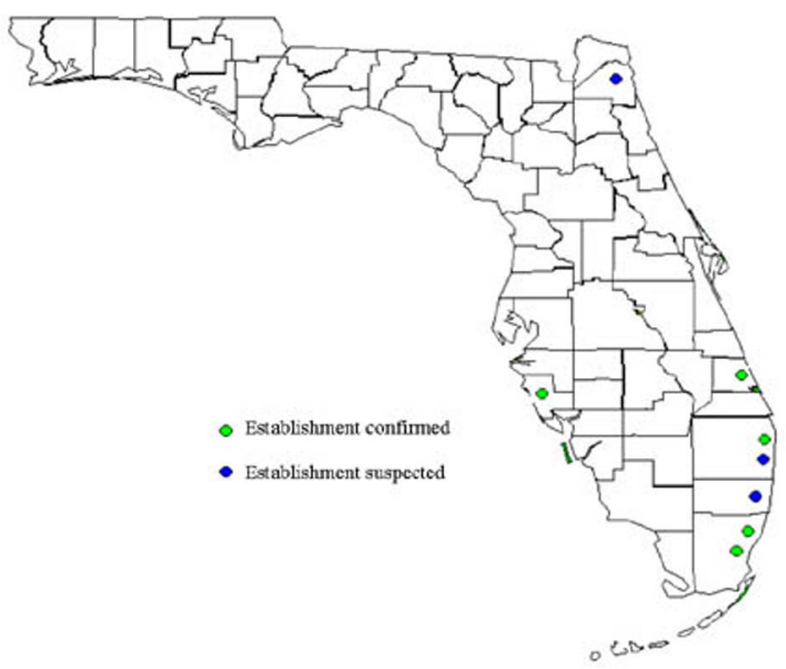

Figure 1. Distribution of the Caribbean crazy ant, Paratrechina pubens Forel, in Florida. Credits: John Warner, University of Florida

\section{Description}

Paratrechina pubens is part of a group of ants referred to as "crazy ants" due to their quick and erratic movements. The Caribbean crazy ant is a medium-small (2.6-3 mm long), monomorphic, golden-brown to reddish-brown ant. The body surface is smooth and glossy, and covered with dense pubescence (hairs). After feeding, the ant's gaster (rear portion of the abdomen) will appear to be striped due to stretching of the light-colored membrane connecting segments of the gaster. Antennae have 12 segments with no club. The antennal scape is nearly twice the width of the head. This ant has one petiolar segment and does not sting.

Similar ants: Paratrechina guatemalensis (Forel 1885), the Guatemalan crazy ant, has pale middle and hind coxae, shorter, stouter, and darker pilosity (Davis 2003, personal communication), and is notably smaller than pubens, total length 2.0 to 2.5 $\mathrm{mm}$ as compared to 2.6 to $3.0 \mathrm{~mm}$ for pubens (Trager 2004 personal communication). Deyrup et al. (2000) state that $P$. guatemalensis is a common species in Dade, Broward and Monroe Counties, but is less common farther north to Hillsborough and Indian River counties, and Deyrup (2002) adds that it is found in south Florida, north to Sarasota and Indian River counties.

Prenolepis imparis (Say 1836), the false or small honey ant, has a severely constricted "hour-glass-

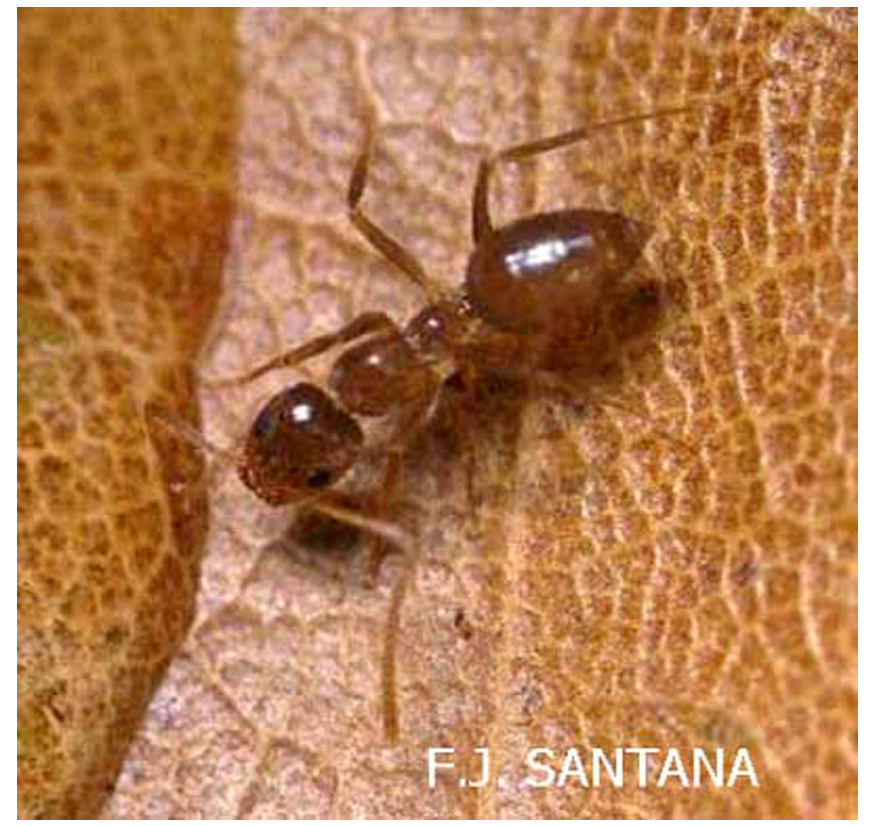

Figure 2. A Caribbean crazy ant, Paratrechina pubens Forel, worker. Credits: F. J. Santana, Sarasota County

shaped" alitrunk (mesosoma), and is found in north Florida, south into Orange County (Deyrup 2002).

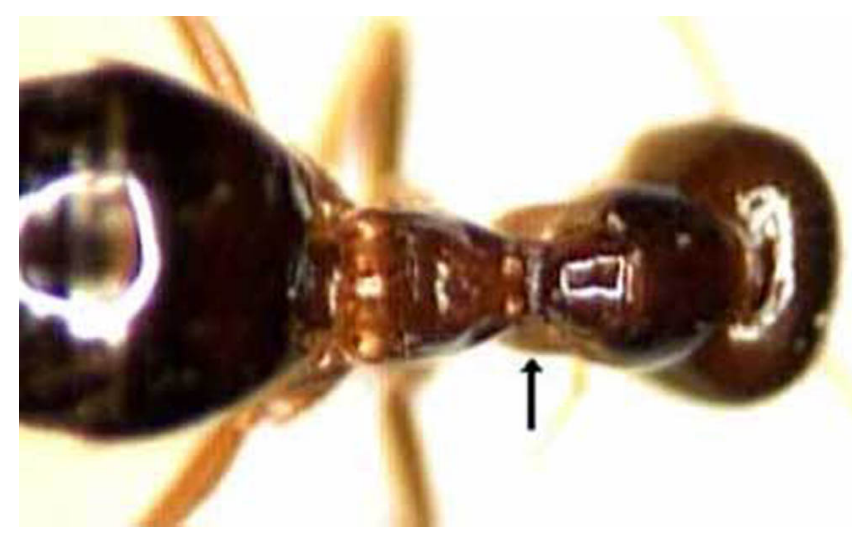

Figure 3. The false or small honey ant, Prenolepis imparis (Say). Arrow shows constriction forming an "hour-glass" shaped alitrunk. Credits: Tim Linksvayer, Carleton College

\section{Life Cycle}

Little is known of the $P$. pubens life cycle. During a cold winter morning in West Palm Beach, Florida, one de-alate queen and several winged males were observed in a soil nest under a log, but the entire colony was not examined. In $P$. longicornis (Latreille), a related species, a single colony may have eight to 40 queens (anon. ag.arizona.edu). It is assumed from observations at West Palm Beach that colonies have several hundred thousand individuals and appear to be polydomous (nesting in several locations) and polygamous (multiple queens). 


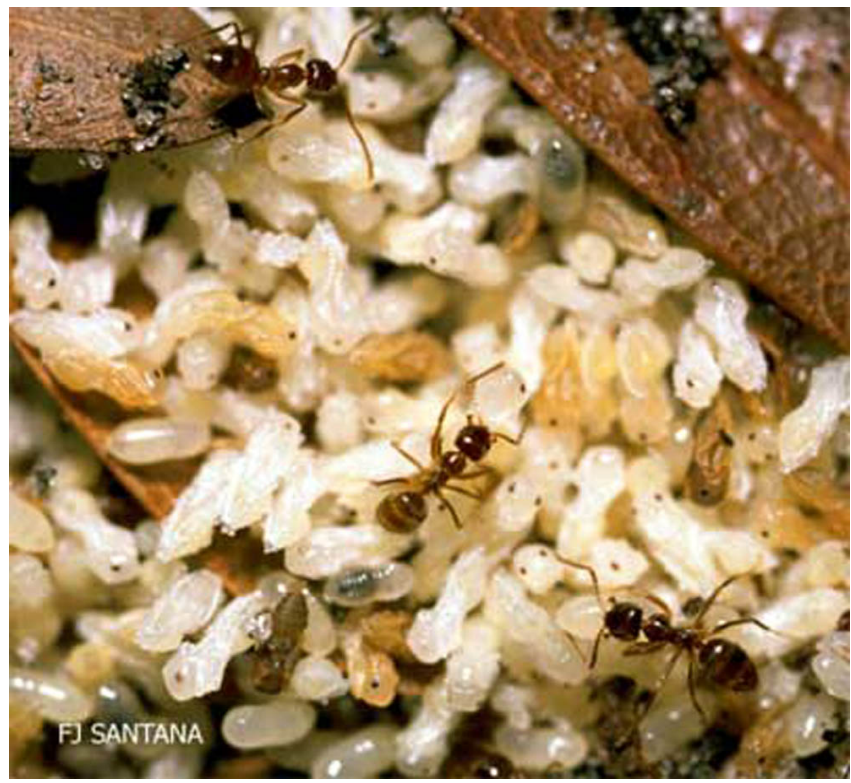

Figure 4. Caribbean crazy ant, Paratrechina pubens Forel, workers tending brood. Credits: F. J. Santana, Sarasota County

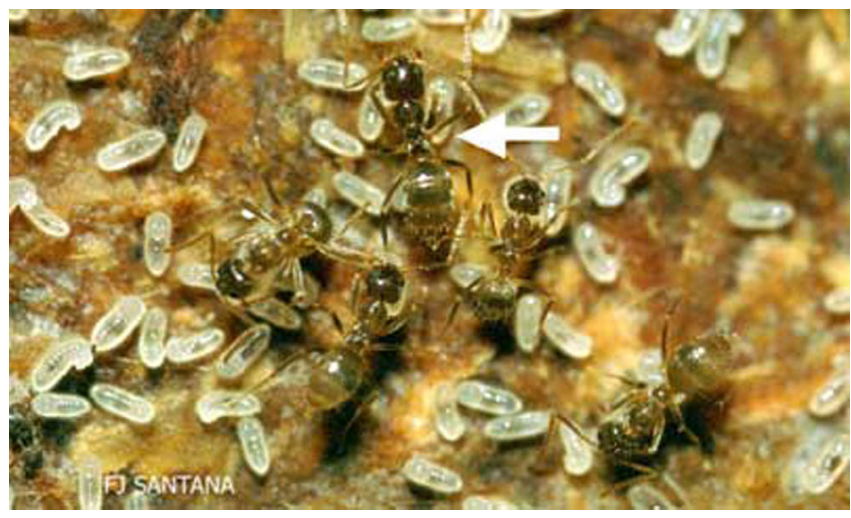

Figure 5. Caribbean crazy ant, Paratrechina pubens Forel, queen (arrow) and workers, tending larvae. Credits: F. J. Santana, Sarasota County

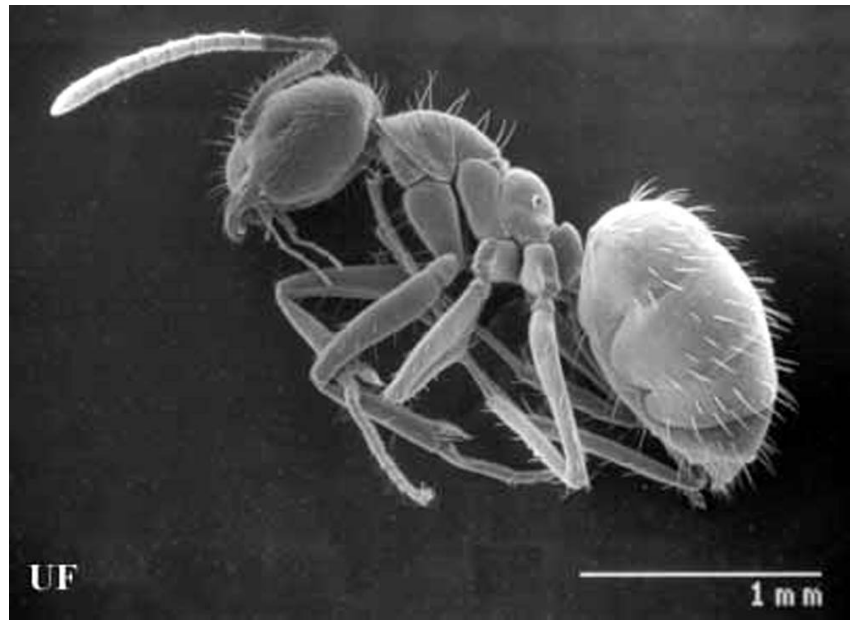

Figure 6. Lateral view of a Caribbean crazy ant, Paratrechina pubens Forel, worker. Credits: John Warner, University of Florida

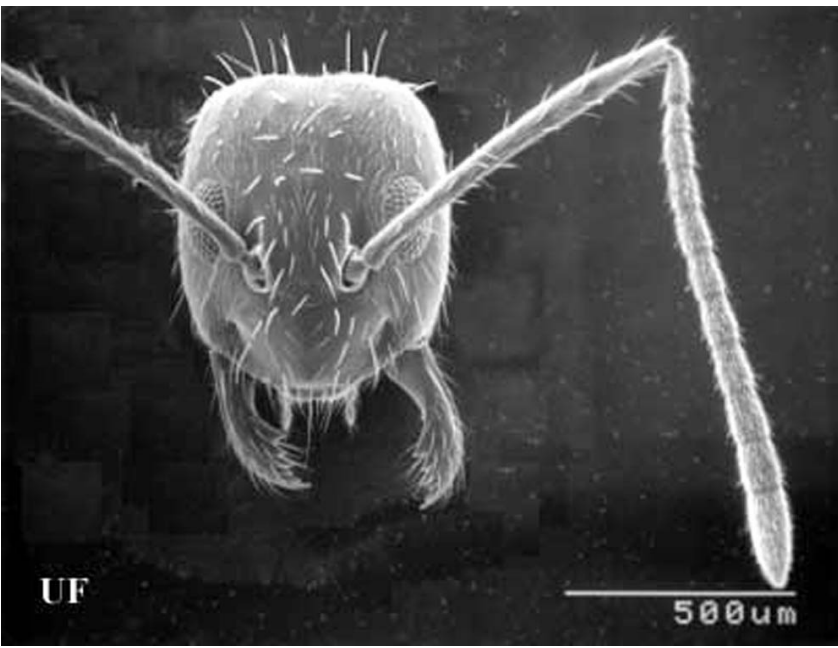

Figure 7. Frontal view of the head of a Caribbean crazy ant, Paratrechina pubens Forel, worker. Credits: John Warner, University of Florida

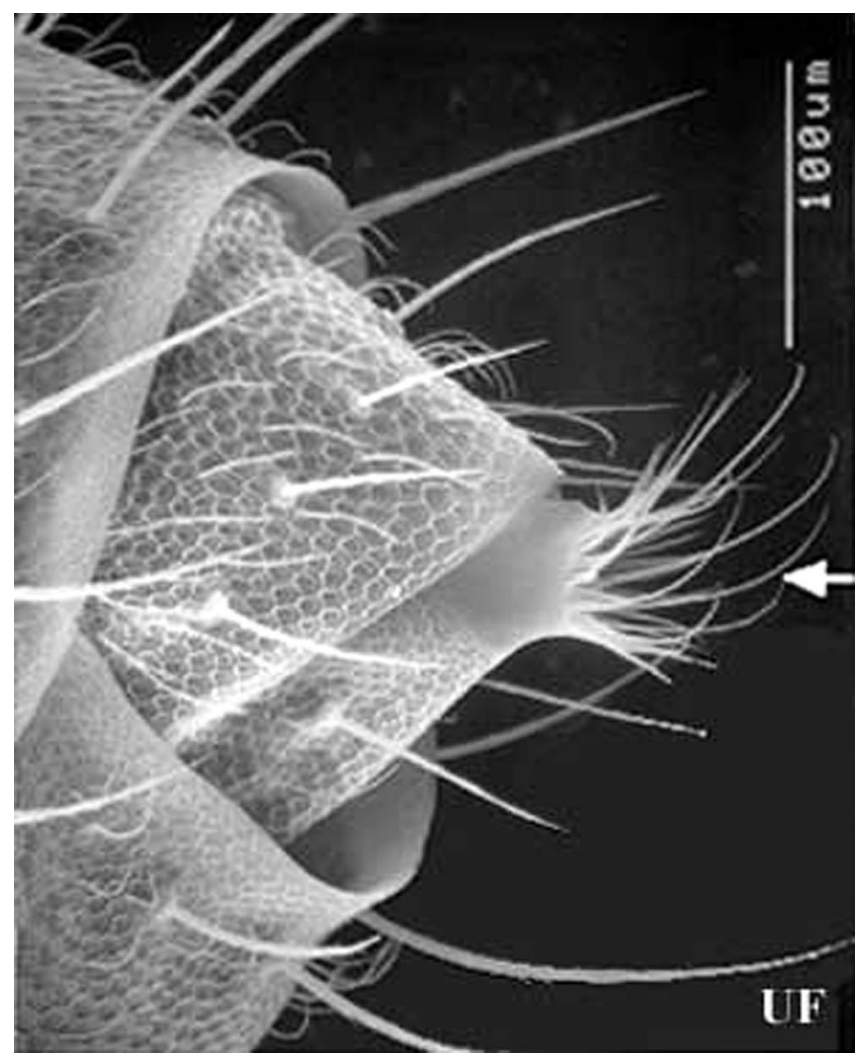

Figure 8. Acidopore (arrow) at apex of gaster of a Caribbean crazy ant, Paratrechina pubens Forel, worker. Credits: John Warner, University of Florida

\section{Foraging and Feeding}

Trails were not observed on a cold morning (approximately $48^{\circ} \mathrm{F}$ ), but as the temperature increased $\left(60^{\circ} \mathrm{F}\right)$, ants foraged from nest sites. Although thick trails were seen along sidewalks, trees, shrubs, and structures, no feeding activity was 


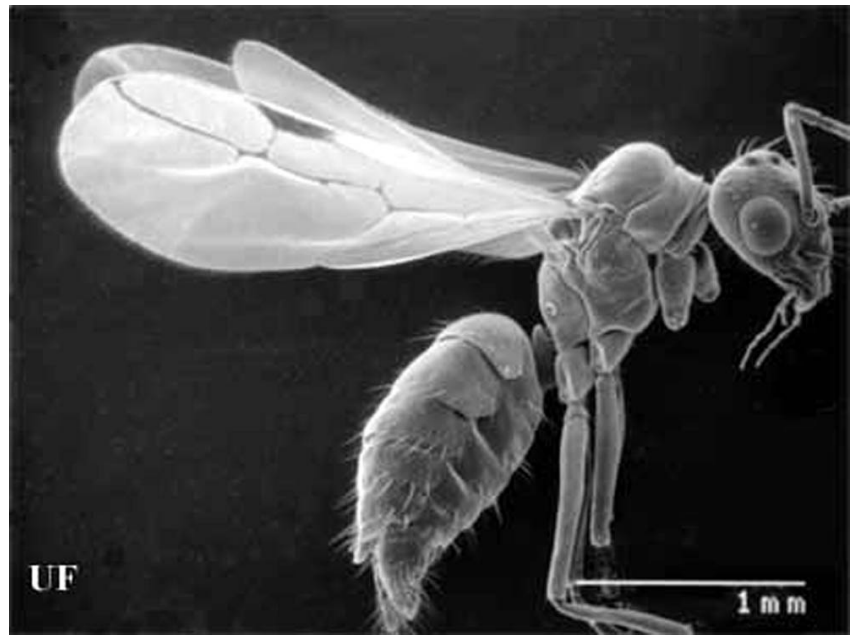

Figure 9. Lateral view of a Caribbean crazy ant, Paratrechina pubens Forel, male reproductive. Credits: John Warner, University of Florida

observed. It is assumed that as other Paratrechina species, $P$. pubens will scavenge for food, feed on dead insects, and tend honeydew producers. Sweet liquid ant bait was fed upon when placed directly on an active trail, but recruitment to the bait was not observed.

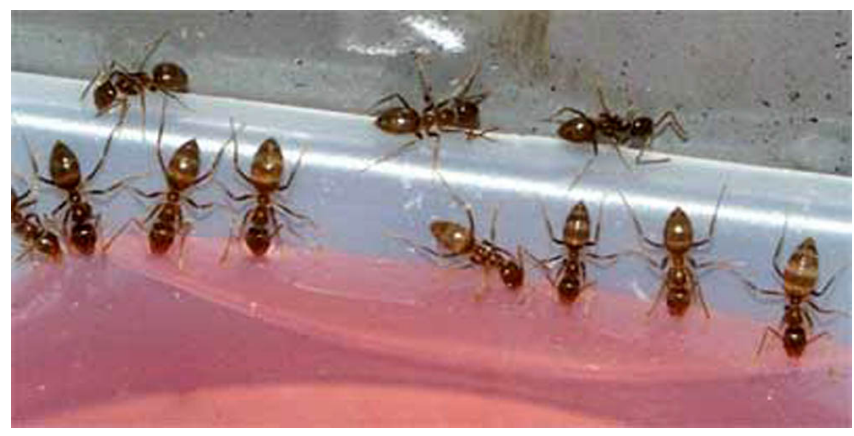

Figure 10. Caribbean crazy ants, Paratrechina pubens Forel, feeding on NecDew@ sweet ant bait. Credits: Rudolph H. Scheffrahn, University of Florida

\section{Nest Sites}

Ants were observed emerging from soffits, between railroad ties used in landscaping, under wooden debris, underground electrical conduits, and cracks in cement. They will probably nest in numerous locations.

\section{Pest Status}

In the last few years, most of the reports of $P$. pubens infestations have come from pest control operators in and around the southeast Florida "Treasure Coast" from West Palm Beach north to

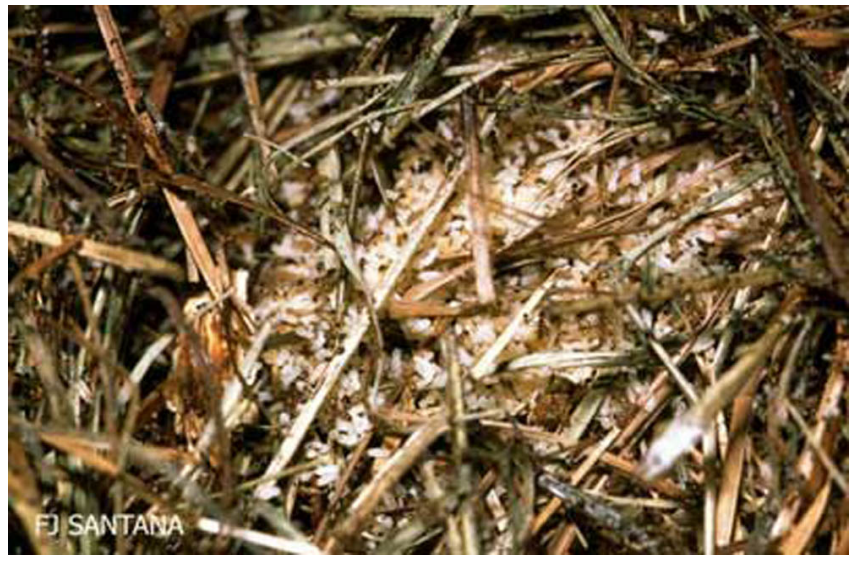

Figure 11. Nest of Carribbean crazy ant, Paratrechina pubens Forel. Credits: F. J. Santana, Sarasota County

Port St. Lucie, where trails consisting of thousands of ants have been observed along sidewalks, buildings, and gardens, causing property owners to complain. Sprays and granular applications of residual insecticides seemingly have had little or no effect in controlling this non-biting nuisance ant.

\section{Management}

Until research is done on management techniques, we recommend the use of contact residual insecticides sprayed along active trails and nest sites to reduce ant populations, followed a few days later by sweet ant baits placed at numerous locations along trails and frequently replaced with fresh bait. Always follow label directions.

\section{Selected References}

Anonymous (undated). Crazy ant (Paratrechina longicornis). What's Bugging You in Arizona. http://ag.arizona.edu/urbanipm/insects/ants/ crazyants.html (19 March 2003).

Deyrup M. 2003. An updated list of Florida ants (Hymenoptera: Formicidae). Florida Entomologist 86:43-48. http://www.fcla.edu/FlaEnt/fe85p658.pdf (21 April 2003).

Deyrup M, Davis L, Cover S. 2000. Exotic ants of Florida. Transactions of the American Entomological Society 126: 293-326.

Forel A. 1893. Formicides de l'Antille St. Vincent, récoltées par Mons. H. H. Smith. Transactions of the Entomological Society of London 1893: 333-418. 
Klotz JH, Mangold JR, Vail KM, Davis, Jr LR, Patterson RS. 1995. A survey of the urban pest ants (Hymenoptera: Formicidae) of peninsular Florida. Florida Entomologist 78: 109-118.

Say T. 1836. Descriptions of new species of North American Hymenoptera, and observations on some already described. Boston Journal of Natural History 1: 209-305.

Trager JC. 1984. A revision of the genus Paratrechina (Hymenoptera: Formicidae) of the continental United States. Sociobiology 9: 51-162. 